\title{
PENGARUH DIABETES SELF MANAGEMENT EDUCATION (DSME) BERBASIS APLIKASI WHATSAPP TERHADAP SELF EFFICACY PADA PASIEN DM TIPE 2 DI PUSKESMAS HAMPARAN PERAK
}

\author{
Agnes Silvina Marbun ${ }^{1}$, Rinco Siregar ${ }^{2}$, Karnirius Harefa ${ }^{3}$, Theresia Yuni Florensia Sidabutar ${ }^{4}$ \\ Fakultas Farmasi dan Ilmu Kesehatan, Universitas Sari Mutiara Indonesia \\ Email : agnesmarbun82@gmail.com \\ Fakultas Farmasi dan Ilmu Kesehatan, Universitas Sari Mutiara Indonesia \\ Email : $\underline{\text { rincosiregar@gmail.com }}$ \\ Fakultas Farmasi dan Ilmu Kesehatan, Universitas Sari Mutiara Indonesia \\ Email : karniharefa74@gmail.com \\ Mahasiswa Program Studi Keperawatan, Universitas Sari Mutiara Indonesia \\ Email : resiaaasnb@gmail.com
}

\begin{abstract}
Diabetes mellitus (DM) is one of the biggest health problems in the world because every year there is an increase in cases. In addition to the increasing number, DM is also known to cause many complications which are divided into two, namely acute complications and chronic complications. The emergence of complications and leading to death in DM patients is due to the low self-efficacy and self-care behavior of DM patients themselves. Self-efficacy is an important factor that is defined as a patient's confidence in maintaining and improving his medical condition. Seeing the importance of self-efficacy in the care of DM patients, increasing patient self-efficacy is needed, namely through the Diabetes Self Management Education (DSME) program. The purpose of this study was to determine the effect of the WhatsApp-based DSME application on the self-efficacy of Type 2 DM patients. This type of research is a Quasy Experiment and the sampling technique used in this study is purposive sampling (Non-Probability sampling). The research design used was Pre-Experiment With Only one Group Pretest - Postest Design. The number of samples was 22 DM type 2 patients. Demographic data collection through questionnaires distributed via google form. The statistical test used was the Paired t test. The results of statistical tests found that there was an effect of WhatsApp-based DSME on the self-efficacy of Type 2 DM patients, with a p value of 0.000 ( $p$ <0.05). This shows that there is an effect of WhatsApp-based DSME on the self-efficacy of Type 2 DM patients at the Hamparan Perak Community Health Center.
\end{abstract}

Keywords : Diabetes Mellitus, DSME, Whatsapp, Self Efficacy 


\section{PENDAHULUAN}

Diabetes Melitus (DM) merupakan salah satu permasalahan kesehatan terbesar di dunia dikarenakan setiap tahunnya terjadi peningkatan kasus (Rahman, 2017). Indonesia merupakan negara ke-7 dari 10 besar negara yang diperkirakan memiliki jumlah penderita DM sebesar 5,4 juta pada tahun 2045 serta memiliki angka kendali kadar gula darah yang rendah (Sugiarta, 2020).

Hasil Riset Kesehatan Dasar (Riskesdas) 2018 memperlihatkan peningkatan angka prevalensi Diabetes di Indonesia yang cukup signifikan, yaitu dari 6,9\% pada tahun 2013 menjadi 8,5\% di tahun 2018, sehingga jumlah penderita di Indonesia mencapai lebih dari 16 juta orang yang berisiko terkena penyakit lain, seperti ; stroke, kebutaan, serangan jantung, gagal ginjal bahkan dapat menyebabkan kelumpuhan dan kematian. Prevalensi penderita DM tertinggi terjadi pada usia 55-64 tahun yakni dengan 6,3\%. Provinsi dengan prevalensi tertinggi yaitu DKI Jakarta (Riskesdas, 2018).

Prevalensi penderita DM di Provinsi Sumatera Utara berjumlah 202,872 jiwa di 33 Kabupaten/ Kota. Prevalensi tertinggi terdapat di Kabupaten Deli serdang dengan jumlah 37,749 jiwa. Selanjutnya, prevalensi tertinggi ke-2 terdapat di Kota Medan dengan jumlah 37,010 jiwa (Profil Kesehatan SUMUT, 2018).

Selain jumlah yang terus bertambah, DM juga diketahui banyak menimbulkan komplikasi yang dibagi menjadi dua yaitu komplikasi akut dan komplikasi kronis. Komplikasi akut meliputi ketoasidosis diabetik, hiperosmolar non ketotik, dan hipoglikemia, yang termasuk komplikasi kronik adalah makroangiopati, mikroangiopati dan neuropati. Banyaknya kasus dan masalah komplikasi menempatkan kasus DM pada peringkat ketiga penyebab kematian tertinggi penyakit tidak menular di Indonesia pada tahun 2016 ( Depkes, 2016).
Timbulnya komplikasi dan berujung kematian pada pasien DM ini dikarenakan rendahnya self efficacy dan perilaku perawatan diri pasien DM itu sendiri. Self efficacy merupakan salah satu faktorpenting yang didefinisikan sebagai kepercayaan pasien dalam menjaga dan meningkatkan kondisi medisnya, rendahnya self efficacy berdampak pada rendahnya keberhasilan perawatan diri pasien DM (Widyanata, 2018). Efikasi dirimempengaruhi bagaimana seseorang berpikir, merasa, memotivasi diri sendiri dan bertindak. Bandura dalam Kott menegaskan bahwa seseorang yang memiliki efikasi diri yang kuat akan menetapkan tujuan yang tinggi dan berpegang teguh pada tujuannya. Efikasi diri mendorong proses kontrol diri untuk mempertahankan perilaku yang dibutuhkan dalam mengelola perawatan diri pada pasien DM (Prihatin dkk, 2019).

Hasil penelitian menunjukkan bahwa lebih dari $50 \%$ pasien DM memiliki pengetahuan dan keterampilan perawatandiri yang rendah sebelum diberikan pendidikan diabetes. Pengetahuan yangrendah juga dapat menyebabkan efikasi diri yang rendah dalam perawatan DM (Prihatin, 2019). Kemudian, penelitian yang dilakukan oleh Ngurah \& Sukmayanti (2014)mengatakan bahwa pasien dengan tingkat pendidikan yang lebih tinggi memiliki efikasi diri dan perilaku perawatan diri yang baik (Pramesthi \& Purwanti, 2020). Efikasi diri yang dimiliki oleh individu akan mempengaruhi individu untuk mengambil keputusan atas perilakunya (Rahman dkk, 2017).

Melihat pentingnya self-efficacy dalam perawatan pasien DM maka peningkatan selfefficacy pasien sangat dibutuhkan. Berbagai intervensi dilakukan untuk meningkatkan kepatuhan pasien dalam menjalankan perawatan mandiri pasien DM, dan untuk meningkatkan self- efficacy pasien pada berbagai domain perawatan diri. Salah satu intervensi yang dapat diberikan adalah pemberian edukasi dan pelatihan bagi pasien (Banna, 2017). Efikasi diri dapatmemberikan pengaruh terhadap perubahan 
perilaku dengan mempengaruhi bagaimana seseorang berpikir, memotivasi diri, dan bertindak (Rahman dkk, 2017).

Menurut Sidani (2009) dalam Widyanata (2018) salah satu intervensi perilaku yang dapat diterapkan pada pasien DM adalah program Diabetes Self Management Education (DSME). DSME merupakan suatu proses memberikan pengetahuan kepada pasien mengenai aplikasi strategi perawatan secara mandiri untuk mengoptimalkan kontrol metabolik, mencegah komplikasi, dan memperbaiki kualitas hidup pasien DM (Ahdiah \& Arofiati, 2019). Diabetes Self Management Education (DSME) merupakan upaya yang dapat dilakukan perawat untuk memberikan edukasi secara berkelanjutan bagi klien DM (Mandasari dkk, 2017).

Menurut Notoatmojo (2003) dalam melakukan Edukasi, agar pesan-pesan kesehatan dapat disampaikan lebih jelas dan masyarakat sasaran dapat menerima pesan orang tersebut dengan jelas dan tepatmaka diperlukan media atau alat bantu. Media tersebut dapat berupa Media cetak, media papan (billboard), dan media elektronik. Strategi pengembangan media promosi kesehatan dalam manajemen pencegahan penyakit sudah banyak dilakukan. Menurut Emilia (2008), penekanan promosi kesehatan terletak pada upaya pendidikan kesehatan melalui media koran, radio, televisi, leaflet, newsletter, majalah, poster, brosur dan sebagainya (Widyanata, 2018).

Saat ini, perkembangan teknologi dan komunikasi terjadi sangat cepat. Perkembangan teknologi informasi dan komunikasi memberi dampak positif terhadap berbagai sendi kehidupan, termasuk bidang keperawatan (Rahmawati dkk, 2018).

Menurut Tavsanli (2013), penggunaan teknologi dalam pengobatan Diabetes dapat memfasilitasi peningkatan komunikasiantar perawat dan pasien, pengumpulan data yang andal, dan penyediaan kehidupan yang nyaman bagi pasien. Media aplikatif berbasis teknologi mobile telah menunjukkan dapat meningkatkan komunikasi penyedia layanan, mudah diakses oleh pasien, menyediakan pilihan yang tepat untuk memfasilitasi proses pengelolaan mandiri, kepatuhan terhadap pengobatan dan pada akhirnya merupakan peningkatan kontrol gula darah (Widyanata, 2018).

Salah satu teknologi keperawatan yang sedang berkembang adalah telehealthnursing atau telenursing. Telenursing didefinisikan sebagai praktik keperawatan jarak jauh menggunakan teknologi telekomunikasi Pada pelaksanaannya, telenursing dapat dilakukan menggunakan berbagai teknologi informasi dan komunikasiseperti aplikasi di smartphone atau komputerdengan memanfaatkan koneksi internet, atau bisa dimulai dengan peralatan sederhana seperti telepon yang sudah banyak dimiliki oleh masyarakat tetapi masih belum banyak dimanfaatkan untuk kepentingan pelayanan kesehatan atau keperawatan. Berdasarkan penelitian yang dilakukan oleh Rahmawati dkk (2018) bahwa telenursing berpengaruh terhadap kenaikan nilai dukungan keluarga penderita DM Tipe 2 dalam menjalankan terapi di wilayah kerja Puskesmas Indralaya.

Menurut Higano (2014) Aplikasi web yang menawarkan program khusus untuk membantu dalam memenuhi kebutuhan pasien belum banyak diteliti manfaatnya. Aplikasi semacam itu harus dirancang untuk memungkinkan individu menyesuaikan program tertentu untuk meningkatkan atau mempertahankan status kesehatannya (Widyanata, 2018). Berdasarkan hasil penelitian Widyanata (2018) Kalender DM yang beliau rancang dengan berbasis android memberikan umpan balik positif dan mendorong orang untuk setiap harimelakukan program nutrisi, aktivitas dan kontrol gula darah secara rutin. Edukasi dengan media elektronik ini telah meningkatkan persepsi self efficacy dan meningkatkan perilaku manajemen diri yang baik yang dapat diihat dari perubahan nilai $\mathrm{HbAlc}$ yang cenderung ke arah terkontrol.

Berdasarkan data awal yang diperoleh di Puskesmas Hamparan Perak jumlah penderita DM Tipe 2 pada bulan Januari tahun 2020 berjumlah 115 kasus, kemudian 
di bulan Februari menjadi 110 kasus, menyusul di bulan Maret menjadi 85kasus, dan terakhir di bulan April menjadi 78 kasus dan berdasarkan informasi dari pihak Puskesmas Hamparan Perak, belum pernah dilakukan Diabetes Self Management Education (DSME) berbasis aplikasi WhatsApp pada Pasien DM.

\section{METODE PENELITIAN}

Desain penelitian Only one Group Pretest - Postest Design , Jenis penelitian ini digunakan untuk mengetahui adanya perbedaan Self efficacy sebelum dan sesudah di berikan Diabetes Self Management Education (DSME) berbasis aplikasi WhatsApp di Puskesmas Hamparan Perak Tahun 2020. Pada penelitian ini populasinya adalah seluruh pasien Diabetes Mellitus Tipe 2 di wilayah kerja Puskesmas Hamparan Perak yang tercatat sebanyak 78 orang. Dalam penelitian ini ditentukan dengan menggunakan tabel Cohen's $d$, one sample design untuk ekperimen dengan settingan power 0.80 dan effect size 0.80 dimana $\alpha 0.05$ maka didapat besar sampel 20 orang. Peneliti juga mengantisipasi apabila ada responden yang drop out dari sampel penelitian menjadi 22 orang.

Tekhnik yang digunakan untuk pengambilan sampel digunakan dengan menggunakan teknik purposive sampling sesuai dengan kriteria inklusi dan eksklusi. Kriteria inklusi dari penelitian ini yaitu pasien sudah di diagnosa Diabetes Melitus Tipe 2 oleh dokter, yang berumur $>45$ tahun, pasien yang bersedia mengikuti program Diabetes Self Managment Education (DSME) berbasis aplikasi WhatsApp. Pasien memiliki dan mampu mengoperasikan handphone (mampu mematikan/menghidupkan handphone, mampu membaca/membuka notification dari aplikasi WhatsApp, mampu membalas chat dari aplikasi WhatsApp) dan memiliki kemampuan membaca dan menulis. Pasien mampu melakukan aktivitas secara mandiri.
Analisa data menggunakan analisis univariat dan bivariat. Analisa univariat dimaksudkan untuk melihat gambaran distribusi frekuensi dari tiap variabel.Analisa bivariat dilakukan untuk menganalisis hubungan antar variabel yang diteliti. Analisa ini dapat diketahui pengaruh program intervensi DSME berbasis aplikasi WhatsApp terhadap Self efficacy pada pasien diabetes mellitus. Jika data berdistribusi normal maka menggunakan uji Paired T- test, jika data tidak berdistribusi normal maka digunakan uji Wilcoxon Test. H0ditolak jika ( $p$-value $<0,05)$, artinya terdapat pengaruh yang signifikan antara satu variabel independen terhadap variabel dependen dan Ha diterima. Sebalikanya $\mathrm{H} 0$ diterima jika ( $p$-value $>0,05$ ), artinya tidak ada pengaruh yang signifikan antara satu variabel independen terhadap variabel dependen dan Ha di tolak. 
HASIL DAN PEMBAHASAN

\section{Analisa Univariat}

\section{Distribusi Frekuensi Berdasarkan Karakteristik Responden}

Tabel 1. Distribusi frekuensi berdasarkan karakteristik responden DM Tipe 2 diPuskesmas Hamparan Perak $(n=22)$

\begin{tabular}{ccc} 
Karakteristik & F & \% \\
\hline Usia (Tahun) & & \\
\hline $45-55$ Tahun & 12 & 54.5 \\
$56-65$ Tahun & 10 & 45.5 \\
\hline Jenis Kelamin & & \\
\hline Laki-laki & 6 & 27.3 \\
Perempuan & 12 & 72.7 \\
\hline Pendidikan & & \\
\hline SMP & 11 & 50.0 \\
SMA & 11 & 50.0 \\
\hline Pekerjaan & & \\
\hline Tidak Bekerja & 17 & 77.3 \\
Wiraswasta & 1 & 4.5 \\
Dll & 4 & 18.2 \\
\hline Lama Menderita DM & & \\
\hline$\leq 1$ Tahun & 1 & 4.5 \\
\hline 1 Tahun & 21 & 95.5 \\
\hline
\end{tabular}

\footnotetext{
Berdasarkan tabel $\quad 1$ menunjukkan bahwa karakteristik responden berdasarkan usia, responden terbanyak pada rentang usia 46 - 55 Tahun tahun sebanyak 12 responden $(54,5 \%)$. Berdasarkan jenis kelamin mayoritasadalah perempuan dengan jumlah 16 orang $(72,7 \%)$ dan berdasarkan pendidikanberjumlah sama SMP (50\%) dan SMA (50\%) Karakteristik responden berdasarkan pekerjaan, responden terbanyak adalah kategori tidak bekerja sebanyak 17 orang $(77,3 \%)$ dan lama menderita DM paling banyak > 1 tahun sebanyak 21 orang $(95,5 \%)$.
}

\section{Distribusi frekuensi sebelum intervensi \\ Tabel 2. Distribusi Frekuensi self efficacy penderita DM Tipe 2 di Puskesmas}

\begin{tabular}{|c|c|c|c|c|c|}
\hline & $\mathbf{N}$ & Min & Max & Mean & $\begin{array}{c}\text { Std. } \\
\text { Deviation }\end{array}$ \\
\hline Pre test & 22 & 42 & 59 & 49.77 & 4.545 \\
\hline Valid N & 22 & & & & \\
\hline (listwise) & & & & & \\
\hline
\end{tabular}

Berdasarkan tabel 2 diketahui bahwa self efficacy penderita DM Tipe 2 di Puskesmas Hamparan Perak sebelum di berikan intervensi nilai minimum 42 dan nilai maksimum 59 dan standard devisiasi 4.545

\section{Distribusi frekuensi sesudah intervensi \\ Berdasarkan tabel 3 diketahui bahwa self efficacy penderita DM Tipe 2 di Puskesmas Hamparan Perak setelah di berikan intervensi nilai minimum 64 dan nilai maksimum 82 dan standard devisiasi 5.853.}

Tabel 3 Distribusi Frekuensi self efficacy penderitaDM Tipe 2 di Puskesmas Hamparan Perak sesudahdi berikan intervensi $(n=22)$

\begin{tabular}{lrrrrr} 
& N & Min Max & Mean & $\begin{array}{c}\text { Std. } \\
\text { Deviation }\end{array}$ \\
\hline Post test & 22 & 64 & 82 & 73.45 & 5.853 \\
\hline Valid N & $\underline{22}$ & & & & \\
\cline { 1 - 1 } (listwise) & & & & &
\end{tabular}




\section{Analisa Bivariat}

Analisa bivariat perbedaan self efficacy penderita DM Tipe 2 di Puskesmas Hamparan Perak sebelum dan sesudah diberikan intervensi Diabetes Self Management Education (DSME) berbasis aplikasi WhatsApp.

Tabel 4. Uji Normalitas nilai self efficacy pre-test dan post-test penderita DM Tipe 2 di puskesmas Hamparan perak 31 Agustus 2020 - 28 Juli 2020

\begin{tabular}{lllllll} 
& \multicolumn{3}{c}{ Kolmogorov-Smirnov $^{\mathrm{a}}$} & \multicolumn{3}{c}{ Shapiro-Wilk } \\
\cline { 2 - 7 } & Statistic & $\underline{\text { Df }}$ & $\underline{\text { Sig. }}$ & $\underline{\text { Statistic }}$ & Df & $\underline{\text { Sig. }}$ \\
Pretest & .121 & 22 & $.20{ }^{*}$ & .966 & 22 & .625 \\
Posttest & .146 & 22 & $.200^{*}$ & .923 & 22 & .086
\end{tabular}

Berdasarkan hasil uji normalitas pada tabel 4. dapat di lihat bahwa nilai pre-test dan post-test menunjukkan sebaran data normal di lihat dari nilai $\mathrm{p}>0.05$ sehingga uji yang digunakan adalah Paired T-test.

Tabel 5. Pengaruh Diabetes Self Management Education (DSME) berbasis aplikasi WhatsApp terhadap self efficacy pasien DM Tipe $2 \mathrm{di}$ Puskesmas Hamparan Perak Tahun 2020 $(n=22)$

Self Efficacy pasien $\quad$ M $\quad$ SD $\quad$ t $\quad$ P-Value DM Tipe 2

\begin{tabular}{lllll}
\hline Sebelum diberikan & 49.77 & 4.545 & -18.627 & .000
\end{tabular}

DSME berbasis

WhatsApp

$\begin{array}{lll}\text { Sesudah diberikan } & 73.45 \quad 5.853\end{array}$

DSME berbasis

WhatsApp

Berdasarkan tabel 5 di atas menunjukkan bahwa hasil uji Paired T-test didapatkan nilai $\mathrm{t}=-18.627$ dan di peroleh nilai $p$ value $=.000(\mathrm{p}<0,05)$, yang berarti ada pengaruh Diabetes Self Management Education (DSME) berbasis aplikasi WhatsApp terhadap self efficacy pasien DM Tipe 2 di Puskesmas Hamparan Perak Tahun 2020.

\section{PEMBAHASAN \\ Karakteristik Responden}

Berdasarkan karakteristik responden berdasarkan usia, responden terbanyak pada rentang usia 46 - 55 Tahun tahun sebanyak 12 responden $(54,5 \%)$. Karakteristik responden berdasarkan usia paling banyak responden memiliki rentang usia $46-55$ tahun. Hal ini sesuai dengan teori yang menyatakan bahwa semakin bertambahnya usia, kemampuan jaringan untuk mengambil glukosa darah semakinmenurun. Diabetes mellitus lebih banyak terjadi pada orang berusia di atas 40 tahun daripada yang lebih muda (Rondonuwu, R, Rompas, \& Bataha, 2016). Hal ini juga disebabkan peningkatan gaya hidup seseorang yang tidak terjaga dalam mengkonsumsi makanan dan kurangnya aktifitas dalam kehidupan sehari-hari (Alfiani, 2017).

Berdasarkan hasil penelitian di atas, karakteristik pada jenis kelamin, responden terbanyak adalah perempuan dengan jumlah 16 orang $(72,7 \%)$. Hal ini sesuai dengan pendapat Corwin (2009) Diabetes melitus tipe II lebih banyak ditemukan pada perempuan dibanding laki-laki. Pernyataan tersebut didukung oleh diabetes gestasional yang terjadi pada wanita hamil yang sebelumnya tidak menyandang diabetes. Meskipun diabetes tipe ini sering membaik setelah persalinan, sekitar $50 \%$ wanita yang mengalami diabetes tipe ini akan kembalike status non diabetes setelah persalinan berakhir, namun risiko untuk mengalami diabetes tipe II lebih besar dari pada wanita hamil yang tidak mengalami diabetes (Dolongseda, dkk, 2017). Hasil penelitian didapatkan data responden berpendidikan SMP (50\%) dan SMA (50\%) memiliki jumlah yang sama. Penelitian yang di lakukan oleh (Wardiyan, 2018). Frekuensi penderita diabetes melitus lebih banyak terjadi pada responden yang berpendidikan dasar sampai menengah, artinyapeningkatan kejadian diabetes juga didorongoleh faktor tingkat pendidikan pasien. Tingkat pendidikan biasanya mampu mempengaruhi kemampuan individu dalam menerima informasi. 
Karakteristik responden berdasarkan pekerjaan, responden terbanyak adalah kategori tidak bekerja sebanyak 17 orang $(77,3 \%)$. Berdasarkan data tersebut, sebagain responden adalah tidak bekerja, artinya mayoritas responden kurang memiliki aktivitas fisik. Berdsarkan penelitian yang di lakukan oleh(Dolongseda, 2018) Kurangnya aktivitas merupakan salah satu faktor yang ikut berperan yang meyebabkan resistensi insulin pada diabetes melitus tipe II. individu yang aktif memiliki insulin dan profil glukosa yang lebih baik dari pada individu yang tidak aktif. Mekanisme aktivitas fisik dalam mencegah atau menghambat perkembangan diabetes melitus tipe II.

Data lama menderita DM paling banyak $>1$ tahun sebanyak 21 orang $(95,5 \%)$ Berdasarkan hasil penelitian tersebut dapat diketahui bahwa responden yang menderita diabetes melitus tipe II dengan porposi terbanyak dalam rentang >

1 tahun. Pasien yang menderita diabetes mellitus dengan jangka waktu lama lebih mampu beradaptasi dengan lingkungan, jika mampu mengatur distress emosional dan memberikan perlindungan diri akan stress dan cemas dengan pengelolaan stress yang baik. Sehingga dapat membantu dalam pencegahan dan pengelolaan DM (Inggit, 2020).

\section{Self efficacy pada pasien DM Tipe 2 sebelum diberikan Diabetes Self Management Education (DSME) berbasis aplikasi WhatsApp}

Hasil penelitian yang dilakukan di Puskesmas Hamparan Perak sebelum diberikan Diabetes Self Management Education (DSME) berbasis aplikasi WhatsApp diperoleh hasil bahwa nilai minimum self efficacy pasien DM Tipe 2 yakni 42 dan nilai maksimum 59 (tabel 4.2). Hal ini dibuktikan dari hasil kuisioner DSMES yang telah diisi oleh responden. Kuesioner ini terdiri dari 20 item dengan skala likert 1-5. Nilai 1 untuk jawaban tidak yakin, 2 untuk jawaban kurang yakin, 3 untuk jawaban cukup yakin, 4 untuk jawaban yakin, 5 untuk jawaban sangat yakin. Rentang nilai efikasi diri adalah 20- 100.

Hasil penelitian berdasarkan tabel 4.2 juga menunjukkan bahwa nilai rata- rata self efficacy pasien DM tipe 2 sebelum diberi intervensi adalah 49.77. Berdasarkan hasil kuisioner DMSES yang telah diisi oleh reponden juga menunjukkan mayoritas responden memilih nilai 2 (kurang yakin) dan nilai 3 (cukup yakin). Self efficacy dalam penelitian ini merupakan keyakinan pasien DM Tipe 2 dalam melakukan perawatan diri. Menurut Bandura dalam (Herawati, 2015) proses terbentuknya efikasi diri salah satunya dari kognitif atau pengetahuan. Dalam hal ini tindakan yang dilakukan seseorang yang berasal dari pikirannya. Kemudian pemikiran tersebut memberi arahan bagi tindakan yang dilakukan. Hal ini di dukung hasil wawancara peneliti saat melakukan penelitian pada pasien penderita DM Tipe2, sebagian besar responden kurang yakin dalam memilih makanan dari beragam makanan yang ada dan tetap menjaga pola makan yang sehat, di buktikan dengan kuisioner (P5) yang telah diisi responden. Penyebabnya adalah kurangnya pengetahuan responden mengenai pemilihan makanan/ diet sehingga menyebabkan tidak terkontrolnya pengelolaan dalam perawatan diri. Hal tersebut berdampak pada berat badan para responden yang tidak ideal.

Penelitian yang sama juga di ungkapkan oleh Prihatin, dkk (2019). Pengetahuan yang rendah dapat menyebabkan efikasi diri yang rendah dalam perawatan DM Efikasi diri mempengaruhi bagaimana seseorang berpikir, merasa, memotivasi diri sendiri dan bertindak. Efikasi diri mendorong proses kontrol diri untuk mempertahankan perilaku yang dibutuhkan dalam mengelola perawatan diri pada pasien.

Oleh karena itu, self efficacy sangat perlu di perhatikan oleh penderita DM Tipe

2 karena sangat mempengaruhi perilaku dalam mengelola perawatan dirinya. Perilaku yang diharapkan dapat dirubah oleh 
pasien DM adalah mengenai gaya hidup dan kebiasaan yang dapat memperburuk kondisi pasien, diantaranya adalah pengaturan diet, aktifitas atau latihan (olahraga) secara teratur, pemantauan gula darah, pengobatan, dan perawatan kaki (Banna, 2017).

Diabetes Self Management Education (DSME) merupakan upaya yang dapat dilakukan perawat untuk memberikan edukasi secara berkelanjutan bagi klien DM. Penelitian yang sama juga di ungkapkan oleh Kurniawati, dkk (2019) bahwa DSME merupakan salah satu bentuk edukasi yang efektif diberikan kepada pasien DM karena pemberian DSME dapat meningkatkan pengetahuan, sikap, dan perilaku pasien dalam melakukan perawatan mandiri. Dengan adanya pemberian DSME pada pasien DM dalam penelitian tersebut, pasien memperoleh informasi terkait perawatan mandiri DM. Pengetahuan, keterampilan, dan status psikologis pasien mengalami peningkatan, sehingga pasien mulai melakukan perawatan mandiri terhadap penyakitnya.

\section{Self efficacy pada pasien DM Tipe 2 sesudah diberikan Diabetes Self Management Education (DSME) berbasis aplikasi WhatsApp}

Hasil penelitian yang dilakukan di Puskesmas Hamparan Perak sesudah diberikan Diabetes Self Management Education (DSME) berbasis aplikasi WhatsApp diperoleh hasil bahwa nilai minimum self efficacy pasien DM Tipe 2 yakni 64 dan nilai maksimum 82 (tabel 4.3). Hal ini dibuktikan dari hasil kuisioner DMSES yang telah diisi oleh responden. Kuesioner ini terdiri dari 20 item dengan skala likert 1-5.

Hal ini membuktikan bahwa terjadi peningkat self efficacy pada pasien DM Tipe 2 di Puskesmas Hamparan Perak setelah di berikan Diabetes Self Management Education (DSME) berbasis aplikasi WhatsApp. Komponen DSME yang diajarkan selama pemberian DSME kepada pasien DM dalam penelitian ini adalah pengetahuan dasar tentang DM, pengaturan nutrisi/diet, olah raga atau latihan fisik, perawatan kaki, senam kakidan stress. Hal ini membuktikan bahwa Diabetes Self Management Education (DSME) berbasis aplikasi WhatsApp yang diberikan kepada responden efektif untuk meningkat self efficacy penderita DM Tipe 2 dalam melakukan perawatan diri.

$$
\text { Penelitian Lari, dkk (2018) }
$$
menunjukan hasil yang sama dengan penelitian ini. Pemberian edukasi dengan menggunakan media elektonik yakni berupa CD berisi edukasi dan melalui SMS dapat meningkatkan self efficacy secara signifikan. Menurut Bandura dalam (Herawati, 2015) proses terbentuknya efikasi diri salah satunya dari kognitif atau pengetahuan. Dalam hal ini tindakan yang dilakukan seseorang yang berasal dari pikirannya. Kemudian pemikiran tersebut memberi arahan bagi tindakan yang dilakukan. Jika semakin tinggi pengetahuan, tingkat pendidikan, dan pekerjaan yang dimiliki akan memberikan konstribusi terhadap terbentuknya efikasi diri yang tinggi dan efikasi diri yang tinggi tidak dapat lepas dari adanya faktor-faktor yang mempengaruhi seperti pengalaman individu sebelumnya, pengalaman orang lain yang sama, persuasi sosial maupun keadaan fisiologis dan emosional.

Penelitian yang sama juga di ungkapkan oleh Kurniawati, dkk (2019) bahwa DSME merupakan salah satu bentuk edukasi yang efektif diberikan kepada pasien DM karena pemberian DSME dapat meningkatkan pengetahuan, sikap, dan perilaku pasien dalam melakukan perawatan mandiri. Dengan adanya pemberian DSME pada pasien DM dalam penelitian tersebut, pasien memperoleh informasi terkait perawatan mandiri DM. Pengetahuan, keterampilan, dan status psikologis pasien mengalami peningkatan, sehingga pasien mulai melakukan perawatan mandiri terhadap penyakitnya.

Pada pasien DM, efikasi diri merupakan keyakinan pasien dalam bertindak dan berperilaku sesuai dengan harapan yang diinginkan oleh pasien maupun tenaga kesehatan. Efikasi diri dapat memberikan 
pengaruh terhadap perubahan perilaku dengan mempengaruhi bagaimana seseorang berpikir, memotivasi diri, dan bertindak. Efikasi diri yang dimiliki oleh individu akan mempengaruhi individuuntuk mengambil keputusan atas perilakunya (Rahaman, dkk. 2017).

Pendapat yang sama juga di kemukakan oleh Hatmawati (2017) Faktor utama yang mempengaruhi perilaku seseorang adalah self efficacy, yaitu keyakinan seseorang tentang kemampuannya sendiri untuk melakukan suatu tindakan yang diinginkan sehingga bisa mencapai hasil yang diinginkan.

\section{Perbedaan self efficacy pasien DM} Tipe 2 sebelum dan sesudah diberikan Diabetes Self Management Education (DSME) berbasis aplikasi WhatsApp

Berdasarkan tabel 5 menunjukkan bahwa ada pengaruh yang signifikan dari pemberian Diabetes Self Management Education (DSME) berbasis aplikasi WhatsApp terhadap self efficacy pasien DM Tipe 2. Hal ini menunjukkan bahwa alat telekomunikasi seperti aplikasi di smartphone dapat menjadi media edukasi bagi para penderita DM Tipe 2. Selain itu, metode edukasi seperti ini dapat mempermudah pasien DM Tipe 2melakukan komunikasi jarak jauh guna melakukan perawatan diri secara mandiri.

Penelitian Lari, dkk menunjukan hasil yang sama dengan penelitian ini. Pemberian edukasi dengan menggunakan media elektonik yakni berupa CD berisi edukasi dan melalui SMS dapat meningkatkan self efficacy secara signifikan. Menurut Bandura dalam (Herawati, 2015) proses terbentuknya efikasi diri salah satunya dari kognitif atau pengetahuan. Dalam hal ini tindakan yang dilakukan seseorang yang berasal dari pikirannya. Kemudian pemikiran tersebut memberi arahan bagi tindakan yang dilakukan. Jika semakin tinggi pengetahuan, tingkat pendidikan, dan pekerjaan yang dimiliki akan memberikan konstribusi terhadap terbentuknya efikasi diri yang tinggi dan efikasi diri yang tinggi tidak dapat lepas dari adanya faktor-faktor yang mempengaruhi seperti pengalaman individu sebelumnya, pengalaman orang lain yang sama, persuasi sosial maupun keadaan fisiologis dan emosional.

Penelitian yang sama juga di ungkapkan oleh Prihatin, dkk (2019) .Pengetahuan yang rendah dapat menyebabkan efikasi diri yang rendah dalam perawatan DM Efikasi diri mempengaruhi bagaimana seseorang berpikir, merasa, memotivasi diri sendiri dan bertindak. Efikasi diri mendorong proses kontrol diri untuk mempertahankan perilaku yang dibutuhkan dalam mengelola perawatan diri pada pasien.

Pada pasien DM, efikasi diri merupakan keyakinan pasien dalam bertindak dan berperilaku sesuai dengan harapan yang diinginkan oleh pasienmaupun tenaga kesehatan. Efikasi diri dapat memberikan pengaruh terhadap perubahan perilaku dengan mempengaruhi bagaimana seseorang berpikir, memotivasi diri, dan bertindak. Efikasi diri yang dimiliki oleh individu akan mempengaruhi individu untuk mengambil keputusan atas perilakunya (Rahaman, dkk. 2017).

Pendapat yang sama juga di kemukakan oleh Hatmawati (2017) Faktor utama yang mempengaruhi perilaku seseorang adalah self efficacy, yaitu keyakinan seseorang tentang kemampuannya sendiri untuk melakukan suatu tindakan yang diinginkan sehingga bisa mencapai hasil yang diinginkan .

Oleh karena itu, self efficacy sangat perlu di perhatikan oleh penderita DM Tipe 2 karena sangat mempengaruhi perilaku dalam mengelola perawatan dirinya. Perilaku yang diharapkan dapat dirubah oleh pasien DM adalah mengenai gaya hidup dan kebiasaan yang dapat memperburuk kondisi pasien, diantaranya adalah pengaturan diet, aktifitas atau latihan (olahraga) secara teratur, pemantauan gula darah, pengobatan, dan perawatan kaki (Banna, 2017).

Proses terbentuknya efikasi diri salah satunya dari kognitif atau pengetahuan. Pengetahuan dapat di berikan kepada pasien 
DM Tipe 2 berupa edukasi kesehatan. Diabetes Self Management Education (DSME) merupakan upaya yang dapat dilakukan perawat untuk memberikan edukasi secara berkelanjutan bagi klienDM. Penelitian yang sama juga di ungkapkan oleh Kurniawati, dkk (2019) bahwa DSME merupakan salah satu bentukedukasi yang efektif diberikan kepada pasien DM karena pemberian DSME dapat meningkatkan pengetahuan, sikap, dan perilaku pasien dalam melakukan perawatan mandiri. Dengan adanya pemberian DSME pada pasien DM dalam penelitian tersebut, pasien memperoleh informasi terkait perawatan mandiri DM. Pengetahuan, keterampilan, dan status psikologis pasien mengalami peningkatan, sehingga pasien mulai melakukan perawatan mandiri terhadap penyakitnya.

Penelitian

Kurniawati

(2019)

mengungkapkan bahwa DSME merupakan salah satu bentuk pendidikan kesehatan terstruktur yang dapat diberikan pada penderita DM tipe 2 yang merupakanelemen kunci dalam perawatan penderita DM dan sangat dibutuhkan untuk meningkatkan hasil perawatan penderita. Literature review yang di lakukan oleh Ahdiah (2019) memaparkan bahwa DSME lebih sering diberikan dalam macam metode yaitu one-to-one, group based, dan tele-medicine.

Tele-medicine merupakan cara penyampaian DSME dengan menggunakan alat-alat telekomunikasi untuk memberikan informasi dan pelayanan kesehatan jarak jauh. Berdasarkan literature review yang dilakukan oleh Ahdiah (2019) menjelaskan bahwa penelitian Tang, dkk (2014) memberikan DSME melalui telepon oleh Peer Leader dan Community Health Worker selama 6 bulan memberikan pengaruh signifikan terhadap manajemen diri penderita DM. Komponen DSME yang diajarkan selama pemberian DSME kepada pasien DM dalam penelitian ini adalah pengetahuan dasar tentang DM, pengaturan nutrisi/diet, olah raga atau latihan fisik, perawatan kaki, senam kaki dan stress. Selama proses pemberian DSME, peneliti mengeksplorasi pengetahuan yang telah dimiliki pasien dan perawatan yang telah dilakukan. Peneliti juga mengeksplorasi perasaan dan keluhan yang dirasakan pasien. Komponen- komponen DSME yang diajarkan kepada pasien dapat meningkatkan pengetahuan dan keterampilan pasien sekaligus memperbaiki perawatan yang dilakukan pasien yang kurang benar.

Dalam penelitian ini Diabetes Self Management Education (DSME) dilakukan berbasis aplikasi WhatsApp. Aplikasi WhatsApp dapat dijadikan sebagai media edukasi, mengingat bahwa peran telekomunikasi sangat memudahkan kehidupan masyarakat di era modern. Penyampaian DSME dengan menggunakan alat-alat telekomunikasi untuk memberikan informasi dan pelayanan kesehatan jarak jauh. Berdasarkan literature review yang di lakukan oleh Ahdiah (2019) menjelaskan bahwa penelitian Tang, dkk (2014) memberikan DSME melalui telepon oleh Peer Leader dan Community Health Worker selama 6 bulan memberikan pengaruh signifikan terhadap manajemen diri penderita DM.

Salah satu aplikasi yang dapat dijadikan media aplikatif untuk memberi edukasi pada Smartphone yakni WhatsApp. WhatsApp Messenger merupakan aplikasi pesan lintas platform yang memungkinkan kita bertukar pesan tanpa biaya SMS, karena WhatsApp Messenger menggunakan paket data internet yang sama untukemail, browsing web, dan lain- lain. Aplikasi WhatsApp Messenger menggunakan koneksi internet 3G, 4G atau WiFi untuk komunikasi data. Dengan menggunakan WhatsApp, kita dapat melakukan obrolan online, berbagi file, bertukar foto, berbagi video, dan lain-lain. Hal ini dapat dijadikan alasan mengapa pemberian Diabetes Self Management Education (DSME) berbasis aplikasi WhatsApp efektif meningkatkan self eficacy pasien DM Tipe 2.

\section{KESIMPULAN DAN SARAN \\ Kesimpulan}

Intervensi DSME selama 4 minggu

dapat meningkatkan self efficacy pasien DM 
tipe 2 di Puskesmas Hamparan Perak. Komponen DSME yang diajarkan selama pemberian DSME kepada pasien DM dalam penelitian ini adalah pengetahuan dasar tentang DM, pengaturan nutrisi/diet, olah raga atau latihan fisik, perawatan kaki, senam kaki dan stress. Selama proses pemberian DSME, peneliti mengeksplorasi pengetahuan yang telah dimiliki pasien dan perawatan yang telah dilakukan. Aplikasi WhatsApp dapat meningkatkan komunikasi penyedia layanan, mudah diakses oleh pasien, menyediakan pilihan yang tepat untuk memfasilitasi proses pengelolaan mandiri sehingga dapat meningkatkan keyakinan diri pasien untuk melakukan perawatan diri secara mandiri dengan baik.

Ada pengaruh Diabetes Self Management Education (DSME) berbasis aplikasi WhatsApp terhadap Self efficacy pada Pasien DM Tipe 2 di Puskesmas Hamparan Perak Tahun 2020 dengan P Value uji paired t test $\mathrm{p}=0,000(\mathrm{p}<0.05)$.

\section{Saran}

Pelayanan kesehatan baik puskesmas maupun rumah sakit diharapkan mampu menyediakan layanan kesehatan jarak jauh denganmenggunakan teknologi modern sekarang, salah satunya melalui aplikasi yang ada di smartphone sehingga tujuan dari edukasi tersebut dapat tercapai. Bagi tenaga kerja khususnya perawat di harapkan mampu menerapkan DSME berbasis aplikasi WhatsApp sehingga dapat mengedukasi pasien DM Tipe 2 dalam melakukan perawatan diri. Penelitian ini masih terbatas pada pemberian Diabetes Self Management Education (DSME) berbasis aplikasi WhatsApp, untuk itu diperlukan penelitian lebih lanjut dengan penambahan variabel dan melibatkan unsur yang berhubungan langsung self efficacy pasien DM.

\section{DAFTAR PUSTAKA}

Ahdiah, Nurul \& Arofiati. 2019. MetodeMetode Penyampaian Diabetes Self Management Education (DSME). 10(1).

Banna, T. 2017. Self-Efficacy Dalam
Pelaksanaan Manajemen Diri (SelfManagement) Pada Pasien Diabetes Mellitus. 7 (2).

Damayanti, Santi. 2017. Diabetes Mellitus dan Penatalaksanaan Keperawatan. Yogyakarta: Nuha Medika.

Decroli, Eva. 2019. Diabetes Melitus Tipe 2. Padang: Pusat Penerbitan Bagian Ilmu Penyakit Dalam.

Dinas Kesehatan Sumatera Utara. 2018. Profil Kesehatan Provinsi Sumatera Utara Tahun 2018.

Dolongseda, Vietryani Fehmi., M, Gresty., B, Yolanda. Hubungan Pola Aktivitas Fisik Dan Pola Makan Dengan Kadar Gula Darah Pada Pasien Diabetes Melitus Tipe Ii Di Poli Penyakit Dalam Rumah Sakit Pancaran Kasih Gmim Manado. Volume (5) Nomor (1).

Fatimah, Restyana Noor. 2015. Diabetes Melitus Tipe 2. 4(5) IDF Diabetes Atlas. Eight Edition, 2017.

Hatmanti, Nety Nawarda. 2017. Hubungan Antara Self Efficacy Dengan Quality Of Life Pada Pasien Diabetes Mellitus Tipe 2 Di Wilayah Kerja Puskesmas Kebonsari Surabaya. 10(2).

Kurniawati, Trina., Huariah, T., Primanda, Y. 2019. Pengaruh Diabetes Self Management Education (DSME) terhadap Self Management pada Pasien Diabetes Mellitus. Jurnal Ilmiah Kesehatan (JIK) Vol XII, No I.

Kristiyani, T. 2016. Self-Regulated Learning. Yogyakarta: Shanata Dharma University Press.

Lari, H., Tahmasebi, R., \& Noroozi, A. (2018). Diabetes \& Metabolic Syndrome: Clinical Research \& Reviews Effect of electroniceducation based on health promotion model on physical activity in diabetic patients. Diabetes \& Metabolic Syndrome: Clinical Research \& Reviews, 12(1), 45-50.

Mandasari, D.P.F., Sustina, F., Krisnana, I. 2017. Pelaksanaan Diabetes Self Management Education Berbasis Health Promotion Model Terhadap Perilaku Kepatuhan Klien Diabetes 
Mellitus (DM)Tipe 2. 8(4).

Manuntung, A. 2018. Terapi Perlaku

Kognitif Pada Pasien Hipertensi.

Malang : Wineka media.

Marbun, Agnes. S. 2020. Hubungan Pelaksanaan Empat Pilar Dengan Kejadian Rehospitalisasi Pada Penderita Diabetes Melitus. Jurnal Kesehatan Surya Nusantara.8(1). 20-28.

Nadziroh, Umi. 2016. Hubungan Efikasi Diri Dengan Mekanisme Koping Pada Pasien Diabetes Melitus (DM) Tipe 2 Di Poli Penyakit Dalam Rsud Dr. Haryoto Lumajang.

PERKENI, 2015. Konsensus Pencegahan dan Pengendalian Diabetes Melitus Tipe 2 di Indonesia.

Pramesthi, I.R \& Purwanti, O.S. 2020. Hubungan Pengetahuan Pengelolaan Diabetes Melitus Dengan Efikasi Diri Pada Penyandang Diabetes Melitus Tipe II.

Prihatin, K., Suprayitna, M., Fatmawati B.R. 2019. Motivasi Terhadap Efikasi Diri Dalam Perawatan Diri Pada Pasien Diabetes Mellitus Tipe 2. 7 (1).

Puspita, Dyah Wiji. 2018. Buku Panduan Pelatihan Kader Kesehatan Kelompok Pendamping Diabetes Self Management Education Berbasis Keluarga (Kp- DSME Keluarga). Semarang: UNISSULA PRESS.

Rahman, H.F., Yulia, Sukmarini, L. 2017. Efikasi Diri, Kepatuhan, dan Kualitas Hidup. 5(1).

Rahmawati, Fuji., Idriansari, A., Wuharyani, P.W. 2018. Upaya Meningkatkan Dukungan Keluarga Penderita Diabetes Mellitus Tipe 2 Dalam Menjalankan Terapi Melalui Telenursing. 5(2).

DOI : https://doi.org/10.51544/imn.v4i2.2071 